\title{
Erratum to aberrant amplitude low-frequency fluctuation (ALFF) and regional homogeneity (ReHo) in generalized anxiety disorder (GAD) and their roles in predicting treatment remission
}

doi: $10.21037 /$ atm-2020-44

View this article at: http://dx.doi.org/10.21037/atm-2020-44

Erratum to: Ann Transl Med 2020;8:1319

Aberrant amplitude low-frequency fluctuation (ALFF) and regional homogeneity (ReHo) in generalized anxiety disorder (GAD) and their roles in predicting treatment remission

In the article that appeared on Page 1319, Vol 8, No 20 (October 2020) Issue of the Annals of Translational Medicine (1), the link "http://dx.doi.org/10.21037/atm-20-6598" is incorrect in the "Introduction" section. The correct link should be "http:// dx.doi.org/10.21037/atm-20-6448".

In addition, the links in the "Footnote" section should be corrected as follows:

\section{Footnote}

Reporting Checklist: The authors have completed the MDAR reporting checklist. Available at http://dx.doi.org/10.21037/atm20-6448

Data Sharing Statement: Available at http://dx.doi.org/10.21037/atm-20-6448

Conflicts of Interest: All authors have completed the ICMJE uniform disclosure form (available at http://dx.doi.org/10.21037/ atm-20-6448). JZ, ZS, XS, YS, LR, and MQ report grants from Huzhou Public Welfare Research Project Social Development (Key Medical and Health) Category (2018GZ39, Xinhua Shen), grants from Social Development Project of Public Welfare Technology Application in Zhejiang Province in 2019 (LGF19H090003, Xinhua Shen), grants from Social Development Project of Public Welfare Technology Application in Zhejiang Province in 2019 (LGF19H090002, Zhongxia Shen), during the conduct of the study. The other authors have no conflicts of interest to declare.

The publisher regrets the error and is sorry for the inconvenience caused.

Open Access Statement: This is an Open Access article distributed in accordance with the Creative Commons AttributionNonCommercial-NoDerivs 4.0 International License (CC BY-NC-ND 4.0), which permits the non-commercial replication and distribution of the article with the strict proviso that no changes or edits are made and the original work is properly cited (including links to both the formal publication through the relevant DOI and the license). See: https://creativecommons.org/ licenses/by-nc-nd/4.0/. 


\section{References}

1. Shen Z, Zhu J, Ren L, et al. Aberrant amplitude low-frequency fluctuation (ALFF) and regional homogeneity (ReHo) in generalized anxiety disorder (GAD) and their roles in predicting treatment remission. Ann Transl Med 2020;8:1319.

Cite this article as: Erratum to aberrant amplitude lowfrequency fluctuation (ALFF) and regional homogeneity (ReHo) in generalized anxiety disorder (GAD) and their roles in predicting treatment remission. Ann Transl Med 2021;9(1):95. doi: 10.21037/atm-2020-44 